\title{
Determination of prostate cancer biomarker acid phosphatase at a copper phthalocyanine-modified screen printed gold transducer
}

\author{
Zina Fredj ${ }^{\text {a, b }}$, Mounir Ben Ali ${ }^{\text {a, b }}$, Mohammed Nooredeen Abbas ${ }^{c}$, Eithne Dempsey ${ }^{\text {d, * }}$ \\ ${ }^{a}$ University of Sousse, Higher Institute of Applied Sciences and Technology of Sousse, GREENS-ISSAT, 4003, Ibn Khaldoun, Sousse, Tunisia \\ b NANOMISENE Lab, LR 16CRMN01, Centre for Research on Microelectronics and Nanotechnology of Sousse, Technopole of Sousse, Sahloul, 4034, Sousse, \\ Tunisia \\ ${ }^{c}$ Electroanal. Lab., National Research Centre (NRC), El Bohouth St., Dokki, 12622 Giza, Egypt \\ d Department of Chemistry, Maynooth University, Maynooth, Co. Kildare, Ireland
}

\section{H I G H L I G H T S}

- Phosphate determination via immobilised novel copper phthalocyanine derivative.

- Acid phosphatase enzyme assay development based on dual detection of enzymatically generated phosphate and naphthol.

- Detection of acid phosphatase in spiked serum samples at clinically relevant concentrations achieved.

\section{A R T I C L E I N F O}

\section{Article history:}

Received 15 August 2018

Received in revised form

25 October 2018

Accepted 18 December 2018

Available online 9 January 2019

\section{Keywords:}

Copper phthalocyanine

Phosphate

Naphthol

Acid phosphatase

Gold screen-printed electrode
G R A P H I C A L A B S T R A C T

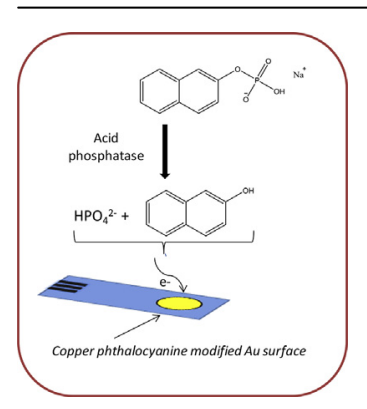

\begin{abstract}
A B S T R A C T
In this work, a novel sensor based on immobilised copper phthalocyanine, 2,9,16,23-tetracarboxylic acidpolyacrylamide ( $\mathrm{Cu}$ (II)TC Pc-PAA) was developed for determination of acid phosphatase (ACP) levels in nanomolar quantities. Detection was based on the measurement of enzymatically generated phosphate, with initial studies focused on phosphate detection at a $\mathrm{Cu}(\mathrm{II}) \mathrm{TC}$ Pc-PAA modified screen-printed gold transducer. The sensor was characterised in relation to operational performance ( $\mathrm{pH}$, response time, stability, linearity, and sensitivity) and common anionic interferents (nitrate, sulphate, chloride, and perchlorate). The functionalised surface also facilitated rapid detection of the enzyme bi-product 2naphthol over the range $5-3000 \mu \mathrm{M}$. Quantitation of ACP was demonstrated, realising a linear response range of $0.5-20 \mathrm{nM}$ and LOD of $0.5 \mathrm{nM}$, which is within the clinical range for this prostate cancer biomarker.
\end{abstract}

() 2019 Elsevier B.V. All rights reserved.

\section{Introduction}

Acid phosphatases (ACPs) represent a family of enzymes that are widespread in nature and can be found in many animal and plant

\footnotetext{
* Corresponding author.

E-mail address: eithne.dempsey@mu.ie (E. Dempsey).
}

species [1]. ACP in human serum is normally found in low concentrations but plays a critical role in many mammalian physiological processes. An increase in acid phosphatase level can cause certain diseases including Gaucher disease, and disorders related to kidneys, veins, and bones are often accompanied by changes in concentrations of ACP [2,3]. The measurement of ACP activity has also been used to assist monitoring of cell viability [4]. The precise detection of ACP activity is of great significance in pathologic 
diagnosis, post-surgical evaluation, and drug screening. The acid phosphatase level changes strikingly during disease progression, providing an important opportunity to contribute towards early stage screening and monitoring.

Prostate cancer (PCa) is the most frequently diagnosed cancer and the second leading cause of cancer deaths in males globally. It is known to be a slow-growing cancer and hence there is a high probability to detect and treat the disease early. Therefore, the development of a convenient, rapid, inexpensive and sensitive method for ACP detection is an important challenge. The current established and most commonly used screening procedures are the PSA (Prostate Specific Antigen) blood test and DRE (Digital Rectal Examination), followed by biopsy of prostate epithelial cells if required [5]. The estimation of ACP activity may help assess earlystage risks and can indicate the stage, location and tentative form of the malignancy, as well as aiding in the follow-up of the disease progression and regression. Acid phosphatase concentration can be determined directly or indirectly by several approaches, including spectrophotometry [6], fluorescence [7], magnetoelastic [8], and electrochemical methods [9]. A need exists to advance noninvasive, early-stage screening methods via rapid point of care diagnostic devices [10] and portable electrochemical sensors based on modified transducers hold great promise as suitable devices for rapid biomedical diagnostics.

Metal phthalocyanines (MPcs) [11] containing one or two metal ions bound to a $\pi$-conjugated ligand have drawn considerable attention as molecular materials that give rise to outstanding electronic and optical properties [12,13]. These properties arise from electronic delocalisation making these compounds applicable in different fields of materials science while being particularly promising as building blocks in nanotechnology. In fact, phthalocyanines have been successfully incorporated into active components of semiconductor and electrochromic devices, information storage systems, liquid-crystal colour displays, and sensors, amongst others. Copper phthalocyanine ( $\mathrm{CuPc}$ ) and phthalocyanine derivatives have attracted considerable interest owing to their unique structural characteristics of aromatic heterocyclic molecules with high symmetry [14]. With the inherent $\pi-\pi$ stacking property of phthalocyanine, special architectures (column, microsphere, and nanofiber) have been fabricated by self-assembly [15], and their potential applications in solar cell, fuel cells, optical limiting materials, electrochemical sensors [16], gas sensors and field-effect transistors demonstrated $[17,18]$.

In this work, we report the development of a new voltammetric sensor for the determination of acid phosphatase based on the simultaneous determination of 2-Naphthol and phosphate at modified screen-printed electrodes. The work exploits electrocatalytic interactions at a gold surface modified by the synthesised derivative of copper phthalocyanine (phthalocyanine, 2,9,16,23tetracarboxylic acid polyacrylamide) and to the best of our knowledge is the first time such an effective electrochemical enzyme assay format is employed based on these materials.

\section{Experimental}

\subsection{Materials}

Tris(hydroxymethyl)aminomethane), tetrahydrofuran (>99.8\%), dimethylsulfoxide, 2-naphthyl phosphate sodium salt, 2-Naphthol $99 \%$, acid phosphatase from wheat germ, sodium nitrate, sodium sulfite, sodium perchlorate, dibasic potassium phosphate $(98 \%)$ sodium acetate, HEPES buffer, potassium phosphate dibasic (98\%), and bovine serum albumin (BSA) were purchased from SigmaAldrich. The water used in all experiments had a resistivity $>18 \mathrm{M} \Omega \mathrm{cm}^{-1} 0.01 \mathrm{M}$ TRIS-HCl buffer solution ( $\mathrm{pH}$ 5.5) was used as the medium for the detection process. The ionophore copper phthalocyanine, C, C, C, C-tetra-carboxylic acid-polyacrylamide $\left(\mathrm{C}_{32} \mathrm{H}_{16} \mathrm{~N}_{8}\right)$, was synthesised at the National Research Centre in Cairo (Egypt) and is composed of four isoindoles connected to nitrogen atoms with a central copper atom.

\subsection{Apparatus and measurements}

The surface morphology and distribution of the copper phthalocyanine were characterised using scanning electron microscopy (JEOL JSM-6390LV model). The electrochemical experiments (cyclic voltammetry) were performed using an electrochemical workstation $\mathrm{CH}$ Instruments Inc. 920, in TRIS- $\mathrm{HCl}$ buffer ( $10 \mathrm{mM}$, pH 5.5), using a conventional three-electrode cell $(5 \mathrm{~mL})$ at room temperature. A modified gold electrode ( $3 \mathrm{~mm}$ diameter) served as the working electrode, while platinum wire $(0.5 \mathrm{~mm}$ diameter $)$ and a standard $\mathrm{Ag} / \mathrm{AgCl}$ electrode (filled with $3 \mathrm{M} \mathrm{KCl}$ ) were used as the counter and reference electrodes, respectively. The gold electrodes were polished with $1.0,0.3$, and $0.05 \mu \mathrm{m}$ alumina powders, sonicated in acetone and ethanol, washed with deionised water and dried using argon at room temperature. Planar screen-printed electrodes: SPE-AT-220 (DropSens), consisted of: (i) a working electrode (WE) gold thin layer $\left(0.125 \mathrm{~cm}^{2}\right.$ geometrical area), (ii) counter electrode (gold, auxiliary electrode) and (iii) a silver pseudoreference electrode (Ag).

\subsection{Synthesis of the copper phthalocyanine, 2,9,16,23- tetracarboxylic acid polyacrylamide (Cu(II)TC Pc-PAA)}

The copper phthalocyanine derivative was prepared by adopting a previously reported procedure $[16,19]$. The ionophore Copper phthalocyanine-2,9,16,23-tetracarboxylic acid (I) and the adduct of copper phthalocyanine-2,9,16,23-tetracarboxylic acid PAA (II) were synthesised according to Scheme 1 and characterised via elemental analysis, UV-Vis and IR spectroscopy [20]. Briefly, the condensation of trimetallic acid anhydride in the presence of urea, ammonium molybdate and copper acetate was used to form the tetra-formamide-phthalocyanine copper. Ionophore (I) was obtained by hydrolysing the tetra-formamide product in an alkaline medium and the ionophore-polymer adduct was synthesised by condensing the carboxylic group of ionophore (I) with the $\mathrm{NH}_{2}$ groups of polyacrylamide by refluxing in dimethylformamide (DMF) at $150^{\circ} \mathrm{C}$ in the presence of polyphosphoric acid (Scheme 1).

\subsection{Preparation of the copper phthalocyanine modified electrode}

$2 \mathrm{mg}$ of $\mathrm{Cu}(\mathrm{II}) \mathrm{TC}$ Pc-PAA was dissolved in $1 \mathrm{~mL}$ (2/3 tetrahydrofuran (THF) $+1 / 3$ dimethylsulfoxide (DMSO). The sensing surface was prepared by drop-casting $10 \mu \mathrm{L}$ of this solution onto the screen-printed electrode (SPE) surface, followed by drying for $24 \mathrm{~h}$ at room temperature. Au SPEs were found to result in the most adherent and effective functionalised surfaces. In the case of SEM analysis, gold electrodes were modified by depositing a layer of copper phthalocyanine $\mathrm{Cu}(\mathrm{II}) \mathrm{TC}$ Pc-PAA via spin coating at $2000 \mathrm{rpm}$ for $60 \mathrm{~s}$.

\subsection{Design of the voltammetric acid phosphatase sensor}

Scheme 2 illustrates the working principle of the sensor with signal generation based on the addition of acid phosphatase in the presence of substrate 2-naphthyl phosphate (3 $\mathrm{mM})$ at the copper phthalocyanine modified sensor surface. The enzymatic reaction produces both 2-naphthol and phosphate anions with resultant electrocatalytic (anodic) signals providing an indirect means of acid 
<smiles>O=C(O)c1ccc2c(c1)C(=O)OC2=O</smiles>

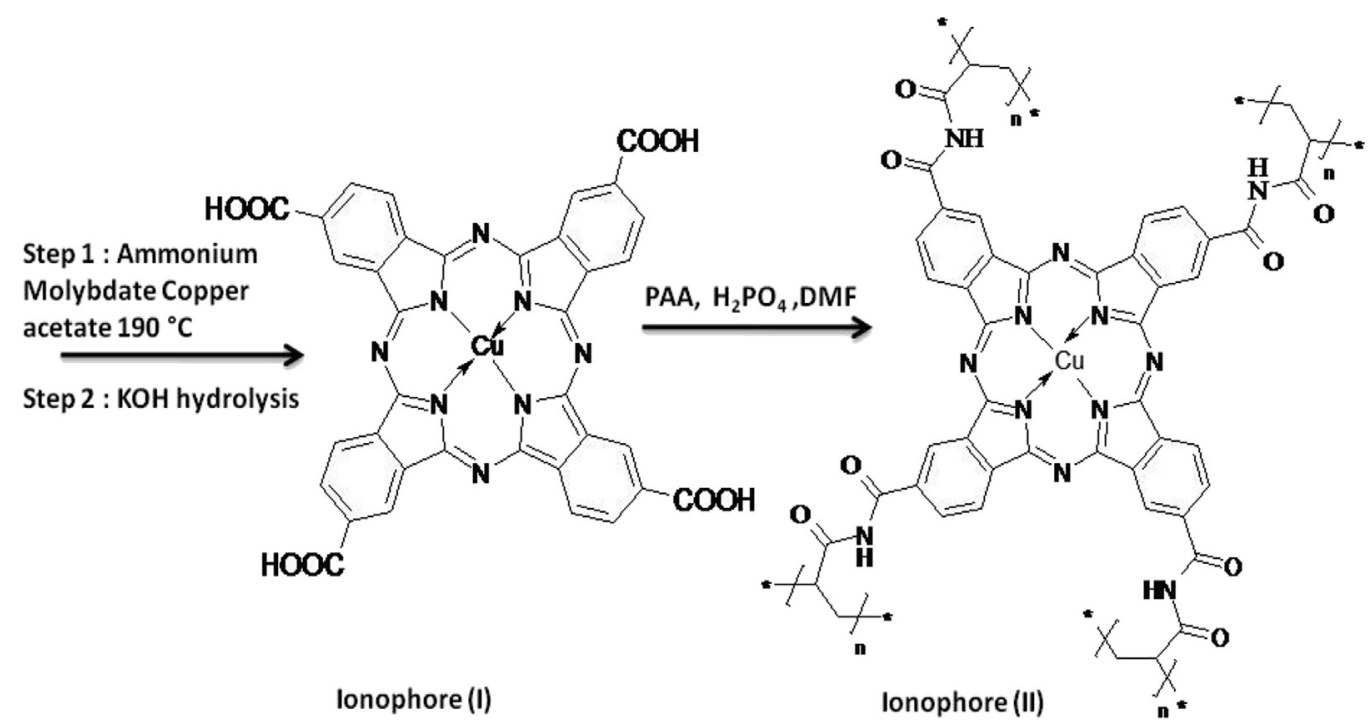

Scheme 1. Synthesis of the novel Copper Phthalocyanine, 2,9,16,23-tetracarboxylic acid-Polyacrylamide (Cu (II)TC Pc-PAA ionophore (II).

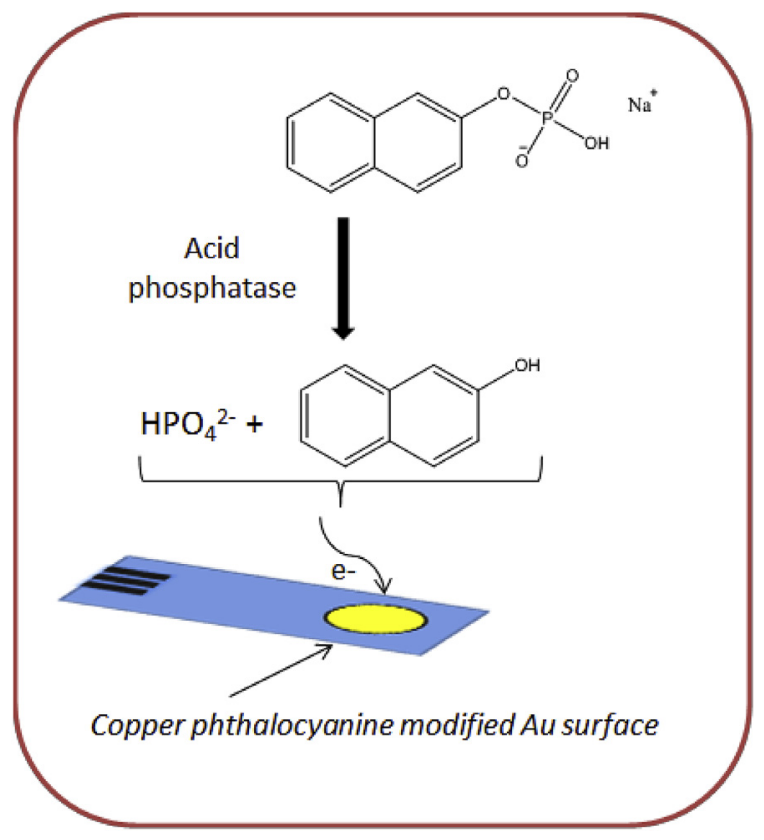

Scheme 2. Schematic representation of the working principle of the acid phosphatase electronic enzyme assay at a modified Au screen printed electrode.

phosphatase quantitation upon incubation in excess substrate (2naphthyl phosphate).

\section{Results and discussion}

\subsection{Surface and spectroscopic characterisation of $\mathrm{Cu}(\mathrm{II}) \mathrm{TC}$ Pc-PAA modified transducer}

The surface morphology of $\mathrm{Cu}(\mathrm{II}) \mathrm{TC}$ Pc-PAA modified gold electrode was characterised by scanning electron microscopy (SEM). Figure 1A shows a uniform distribution on the surface of the electrode indicating the compact deposited film. It was also observed that the surface appeared porous with average grain size ca. $400 \mathrm{~nm}$ [21]. Figure 1B illustrates the Raman spectrum of the $\mathrm{Cu}(\mathrm{II}) \mathrm{TC}$ Pc-PAA derivative with the bend at $1542.57 \mathrm{~cm}^{-1}$ corresponding to heavy metal-nitrogen (M-nitrogen) in-plane stretching and bending vibrations as well as displacement on the $\mathrm{C}-\mathrm{N}-\mathrm{C}$ bridge bend - characteristic of the metallophthalocyanine structure. The bend at $593.7 \mathrm{~cm}^{-1}$ corresponded to benzene ring deformation and bends at $686 \mathrm{~cm}^{-1}$ and $751.7 \mathrm{~cm}^{-1}$ correspond to C-C vibration [22].

\subsection{Electrochemical characterisation of the Cu(II)TC Pc-PAA film}

The bare gold electrode and copper phthalocyanine modified electrodes were tested in the presence and absence of phosphate $\left(\mathrm{H}_{2} \mathrm{PO}_{4}^{-} / \mathrm{HPO}_{4}^{2-}, 10 \mathrm{mM}\right)$ in TRIS- $\mathrm{HCl}$ buffer $(10 \mathrm{mM}, \mathrm{pH} 7.2)$ with the aid of cyclic voltammetry (Fig. 2A). Electrochemical characterisation shows classical Au oxide reduction and oxidation at $\mathrm{E}_{\mathrm{p}}=0.45 \mathrm{~V}$ with a weak anodic process at $1.17 \mathrm{~V}$ vs. $\mathrm{Ag} / \mathrm{AgCl}$ (Fig. $2 \mathrm{~A}$ curve a). Direct phosphate oxidation occurred on the bare gold surface at $\mathrm{E}_{\mathrm{p}}=1.07 \mathrm{~V}$ vs. $\mathrm{Ag} / \mathrm{AgCl}$ [23] with an enhancement of the gold reduction process at $0.38 \mathrm{~V}$ (Fig. $2 \mathrm{~A}$ curve $\mathrm{b}$ ).

Voltammetric signals associated with the phthalocyanine ring are strongly dependent on the metal ion, substituents, electrolyte and deposition method. During the cathodic sweep $\mathrm{Cu}$ (II)TC Pc-PAA ligand deposition/dissolution processes may take place on the gold [24], reflecting protonation of bridging imine groups, and being more evident in acidic medium. Under our neutral $\mathrm{pH}$ conditions, there were weak cathodic $(-0.22 \mathrm{~V})$ and anodic $(0.25 \mathrm{~V})$ processes evident (curve c Fig. 2A), which may correspond to one of the monoelectronic phthalocyanine ligand redox processes [25].

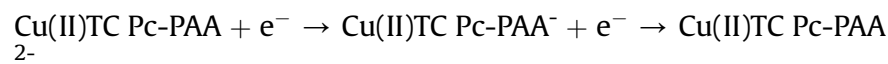

Subsequent oxidation of cathodically pre-adsorbed ligand species/aggregates may be responsible for the anodic signal (shoulder at $0.94 \mathrm{~V}$ ), as indicated by the work of Inzelt et al. with respect to $\mathrm{Cu}(\mathrm{II})$ phthalocyanines on Gold macro electrodes [25], while the visibly surface confined peak at $1.16 \mathrm{~V}$ overlaps with the gold oxide signal at a bare electrode, and may have a contribution from the oxidised form $\mathrm{Cu}(\mathrm{II}) \mathrm{TC}$ Pc-PAA ${ }^{+}$.

Upon addition of phosphate (Fig. 2A curve d) there was an anodic shift in the first ligand oxidation process to $0.55 \mathrm{~V}$ and a significant enhancement in both the wave $(0.99 \mathrm{~V})$ and the main anodic peak at $1.4 \mathrm{~V}$. The $\mathrm{Au}$ oxide reduction $\left(\mathrm{E}_{\mathrm{p}}=0.45 \mathrm{~V}\right)$ also 
(A)

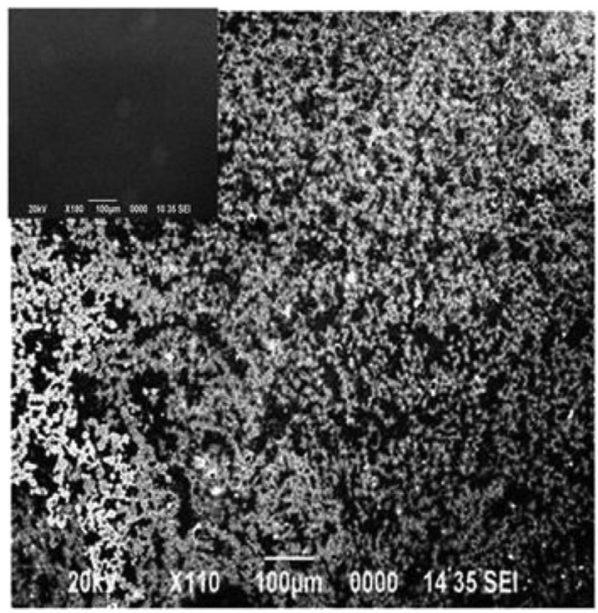

(B)

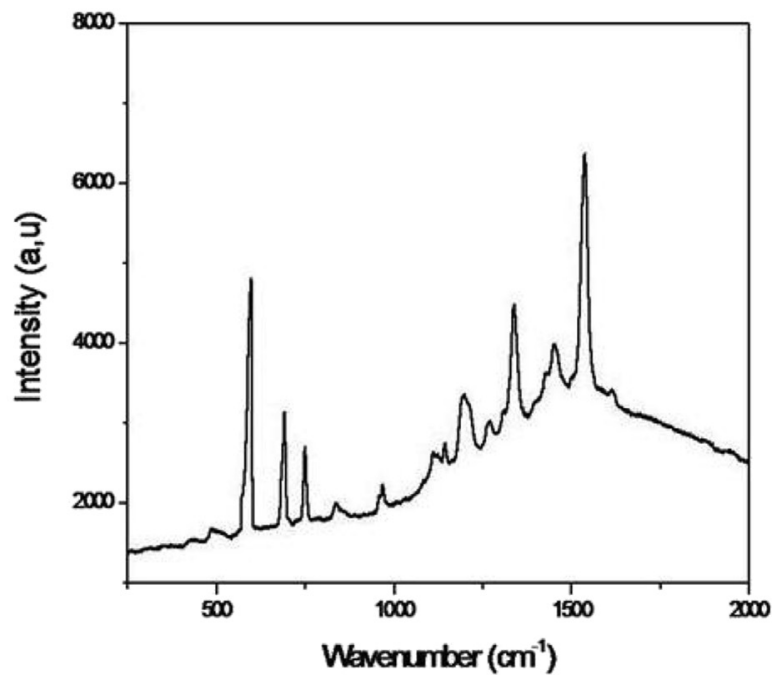

Fig. 1. (a) SEM images, and (b) RAMAN spectra of the $\mathrm{Cu}(\mathrm{II}) \mathrm{TC}$ Pc-PAA thin layer deposited onto gold planar structures via spin coating

appeared enhanced in the presence of phosphate at the modified surface while the main anodic process at $1.2 \mathrm{~V}$ vs. $\mathrm{Ag} / \mathrm{AgCl}$ responded to increasing phosphate concentration (curves c, d). The presence of the immobilised $\mathrm{Cu}$ (II)TC Pc-PAA species facilitated the phosphate anion electrooxidation signal, resulting in significant increase in anodic current at the $\mathrm{Cu}(\mathrm{II}) \mathrm{TC}$ Pc-PAA modified gold electrode $(35 \mu \mathrm{A})$ relative to the bare electrode $(10 \mu \mathrm{A})$.

The influence of scan rate on the immobilised $\mathrm{Cu}$ (II)TC Pc-PAA film in TRIS- $\mathrm{HCl}$ buffer ( $10 \mathrm{mM}, \mathrm{pH}=7.2$ ) was examined (Fig. $2 \mathrm{~B}$ ) over the range $10-800 \mathrm{mV} / \mathrm{s}$. Peak current $\left(I_{p}\right)$ increased linearly with respect to scan rate $(\mathrm{U})$ from 10 to $100 \mathrm{mV} / \mathrm{s}$ (insert Fig. 2B), confirming the surface-confined film behaviour of the peak at $E_{p}=1.12 \mathrm{~V}$ over this range. Higher scan rates caused deviation from this relationship indicating a diffusional limitation to the current response within the thick film [26]. From the observations, it was concluded that the electrochemical process consisted of a mixture of diffusion and adsorption controlled processes, depending on the scan rate. From the slope of the linear plot of $I_{p}\left(\right.$ taken at $E_{p}=1.12 \mathrm{~V}$ ) vs. $\cup$ (scan rate) the surface concentration of the electroactive species $(\Gamma)$ was estimated to be $2.79 \times 10^{-4} \mathrm{~mol} \mathrm{~cm}^{-2}$ according to the equation below [27]:

$I p=\frac{n^{2} F^{2} A \Gamma v^{2}}{4 R T}$

Insert 2 of Fig. 2B shows a linear relationship between log peak current vs. log scan rate plot, with a slope $>0.5$ indicating a mixed diffusion/adsorption process [28].

\subsection{Sensitivity and selectivity of $\mathrm{Cu}(\mathrm{II}) \mathrm{TC}$ Pc-PAA modified transducers towards phosphate ion detection}

The analytical response towards phosphate was investigated at physiological $\mathrm{pH}$ (dominant anionic species at this $\mathrm{pH}$ are $\mathrm{H}_{2} \mathrm{PO}_{4}^{-} /$ $\mathrm{HPO}_{4}^{2-}$ ). The voltammetric current response at $1.17 \mathrm{~V} v s . \mathrm{Ag} / \mathrm{AgCl}$ increased significantly with increasing phosphate concentrations over the range $0.1 \mathrm{nM}-10 \mathrm{mM}$ with a coefficient of determination $\left(\mathrm{R}^{2}\right)$ of 0.9979 and limit of detection (LOD) of $5 \times 10^{-10} \mathrm{M}$ (defined as $3 \sigma /$ slope; $n=3$ ) (insert Fig. 3 ). The signal reproducibility was examined by measuring phosphate anion concentration at $1.0 \times 10^{-8}, 1.0 \times 10^{-6}$ and $1.0 \times 10^{-4} \mathrm{M}$ with three replicates - the coefficients of variation were $4.2 \%, 3.3 \%$, and $5.6 \%$ respectively.

The robustness of the copper phthalocyanine modified gold electrodes was evaluated by measuring the response to $1 \times 10^{-5} \mathrm{M}$ phosphate every 5 days. The developed platform was stored dry at room temperature when not in use. The response slope was almost completely stable for more than one month (40 days); the sensor retained $93 \%$ of its initial response, thereby demonstrating the stability of the transducer surface. A selectivity study for quantitative determination of phosphate on the copper phthalocyanine modified gold electrode was investigated by addition of x1000 fold excess of $\mathrm{SO}_{4}^{2-}, \mathrm{NO}^{3-}, \mathrm{Cl}^{-}$and $\mathrm{ClO}_{4}^{-}$in $10 \mathrm{mM}$ Tris- $\mathrm{HCl}$ buffer [29]. The interference effects of these constituents were investigated by examining the phosphate response at the copper phthalocyanine modified gold electrode in the presence of 1000-fold excess of interfering ions. The results are summarised in Table 1 and showed that this excess of $\mathrm{SO}_{4}^{2-}, \mathrm{NO}^{3-}, \mathrm{Cl}^{-}$and $\mathrm{ClO}_{4}^{-}$did not significantly influence the peak current for phosphate at $E_{p}=1.17 \mathrm{~V}$, nor did it significantly influence the sensitivity and detection limit of the phosphate signal. The selection of these anionic interferents was based on the fact that the detection mechanism was indirect (phosphate) ACP measurement reinforced by detection of the redox activity of the second enzymatic product (naphthol).

\subsection{Cyclic voltammetry investigations of 2-naphthol response at the $\mathrm{Cu}(\mathrm{II}) \mathrm{TC}$ PC-PAA modified electrode}

The anodic oxidation of 2-naphthol in buffer solution (TRIS-HCl) at the copper phthalocyanine modified gold electrode was examined over a range of concentrations (a: $0 \mathrm{M}, \mathrm{b}: 10^{-7} \mathrm{M}, \mathrm{c}: 10^{-6} \mathrm{M}, \mathrm{d}$ : $10^{-5} \mathrm{M}$, e: $10^{-4} \mathrm{M}, \mathrm{f}: 10^{-3} \mathrm{M}$ ) and cyclic voltammetric data is shown in Fig. 4. The modified gold electrode displayed a welldefined naphthol oxidation response at $+0.8 \mathrm{~V}$ vs. $\mathrm{Ag} / \mathrm{AgCl}$ over the range examined with associated cathodic wave at $0.7 \mathrm{~V} \mathrm{vs.} \mathrm{Ag/}$ $\mathrm{AgCl}\left(\mathrm{E}_{1 / 2}=0.6 \mathrm{~V}\right)$. 2-Naphthol redox behaviour has been shown to result in irreversible electrochemistry with subsequent formation of polymeric products upon oxidation to the naptholate anion at bare carbon surfaces [30]. This results in poor analytical 

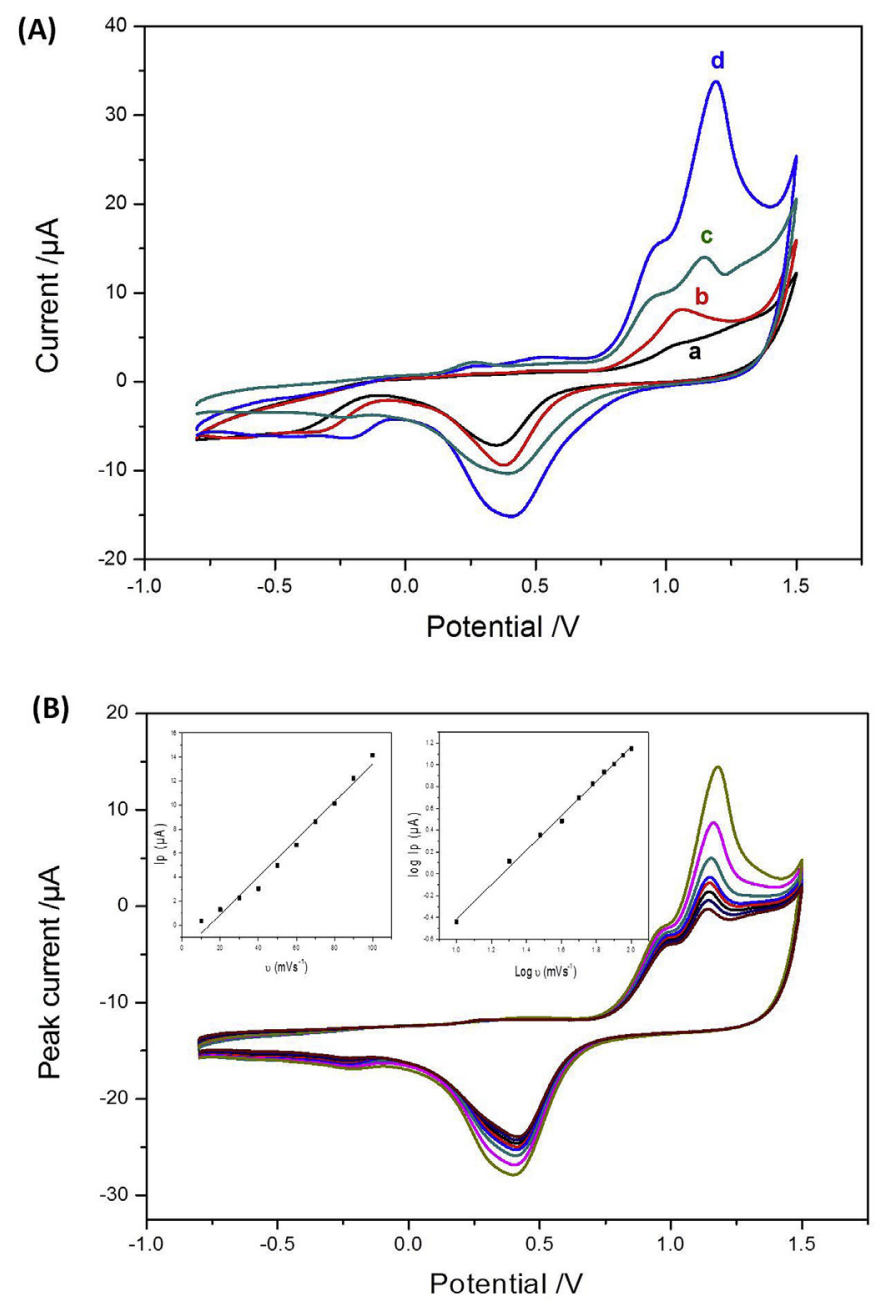

Fig. 2. (A) Cyclic voltammograms recorded in TRIS-HCl for bare electrode (a) and $\mathrm{Cu}(\mathrm{II})$ TC Pc-PAA modified electrode (c), in the absence of phosphate; bare electrode (b) and $\mathrm{Cu}$ (II)TC Pc-PAA modified gold electrode (d) and in the presence of $10 \mathrm{mM}$ phosphate $(u=100 \mathrm{mV} / \mathrm{s}, \mathrm{pH}=7.2)$. (B) Cyclic voltammograms of $\mathrm{Cu}(\mathrm{II}) \mathrm{TC}$ Pc-PAA modified $\mathrm{Au}$ electrode recorded in TRIS-HCl at different scan rates 10, 40, 70, 100, 150, 300, 500, $800 \mathrm{mV} / \mathrm{s}$ - insert shows influence of the scan rate $(10-100 \mathrm{mV} / \mathrm{s})$ on the peak current. (For interpretation of the references to colour in this figure legend, the reader is referred to the Web version of this article.)

performance, while observations in this work indicated that use of Au transducers favour more reversible electrochemical behaviour enabling sensitive and linear detection, thus facilitating effective monitoring of ACP activity.

As the concentration of 2-naphthol increased $(0-1 \mathrm{mM})$, the peak current measured via cyclic voltammetry increased (Fig. 4), with a linear relationship between peak current and 2-naphthol concentration $\left(\mathrm{R}^{2}=0.9963\right)$ over this range (inset Fig. 4) with the equation $\mathrm{Y}=0.92 \mathrm{X}+6.82$ (where $\mathrm{X}$ is the logarithm of 2-naphthol ion concentration $(\mathrm{M})$; and $\mathrm{Y}$ is the peak current $(\mu \mathrm{A})$ )] and limit of detection (LOD) of $7.86 \times 10^{-8} \mathrm{M}$ (defined as $3 \sigma /$ slope; $n=3$ ).

\subsection{Acid phosphatase detection at Cu(II)TC Pc-PAA modified transducers}

In order to optimise the sensor performance for ACP quantitation, optimisation of (A) buffer type, (B) electrolyte $\mathrm{pH}$ and (C) enzyme-substrate incubation time was performed. Fig. $5 \mathrm{~A}$ shows that the signal response (at $\mathrm{E}_{\mathrm{p}}=0.68 \mathrm{~V}$ and $1.11 \mathrm{~V}$ respectively $v s$. $\mathrm{Ag} / \mathrm{AgCl}$ ) of the enzymatic reaction products phosphate and 2-

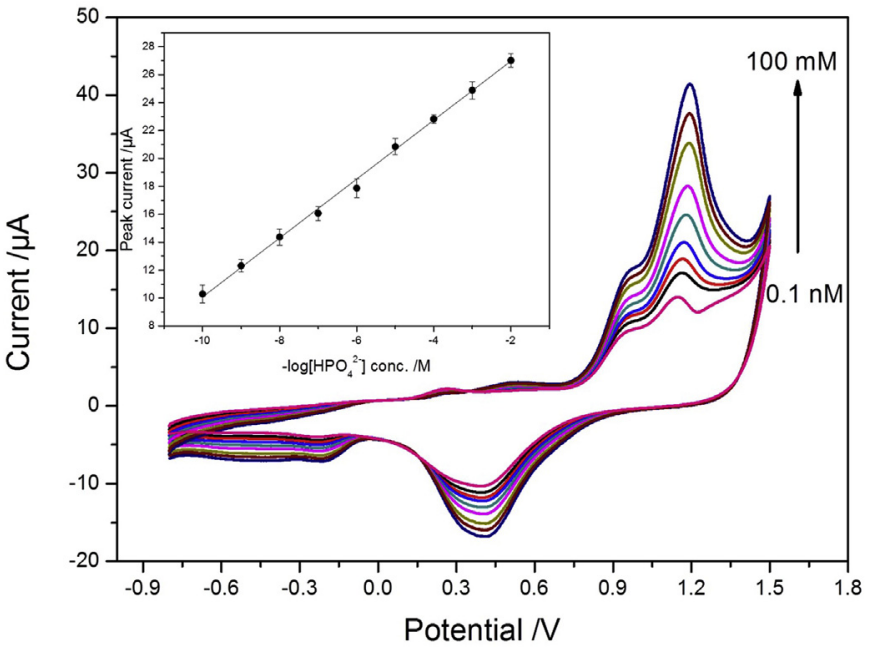

Fig. 3. Voltammetric response towards increasing concentrations of phosphate in TRIS- $\mathrm{HCl}$ buffer $(10 \mathrm{mM}, \mathrm{pH}=7.2)$; (Insert) Calibration curve as a function of phosphate $\left[\mathrm{H}_{2} \mathrm{PO}_{4}^{-} / \mathrm{HPO}_{4}^{2-}\right]$ concentration at the copper phthalocyanine modified gold transducer $[\mathrm{Y}=2.11 \mathrm{X}+31.19$ (where $\mathrm{X}$ is the logarithm of phosphate ion concentration $(\mathrm{M})$; and $\mathrm{Y}$ is the peak current $(\mu \mathrm{A})$ )]. (For interpretation of the references to colour in this figure legend, the reader is referred to the Web version of this article.)

Table 1

Relative \% response, sensitivity and detection limit for the phosphate ion response in the presence of $\mathrm{x} 1000$ fold excess of selected interfering ions $\left(\mathrm{SO}_{4}^{2-}, \mathrm{NO}^{3-}, \mathrm{Cl}^{-}\right.$and $\mathrm{ClO}_{4}^{-}$) at the $\mathrm{Cu}(\mathrm{II}) \mathrm{TC}$ Pc-PAA modified electrode in TRIS- $\mathrm{HCl}$ buffer (10 mM, pH 7.2).

\begin{tabular}{llll}
\hline Target ion & Relative response $(\%)$ & Sensitivity $(\mu \mathbf{A} / \mathbf{M})$ & Detection limit $(\mathbf{M})$ \\
\hline $\mathrm{SO}_{4}^{2-}$ & 95.44 & 37.36 & $1.52 \times 10^{-10}$ \\
$\mathrm{NO}_{3}^{-}$ & 87.84 & 34.12 & $7.64 \times 10^{-10}$ \\
$\mathrm{Cl}^{-}$ & 83.87 & 32.96 & $3.18 \times 10^{-9}$ \\
$\mathrm{ClO}_{4}^{2-}$ & 80.24 & 32.13 & $9.32 \times 10^{-9}$ \\
$\mathrm{HPO}_{4}^{2-}$ & 100 & 39.56 & $8.62 \times 10^{-11}$ \\
& $n=3$ & & \\
\hline
\end{tabular}

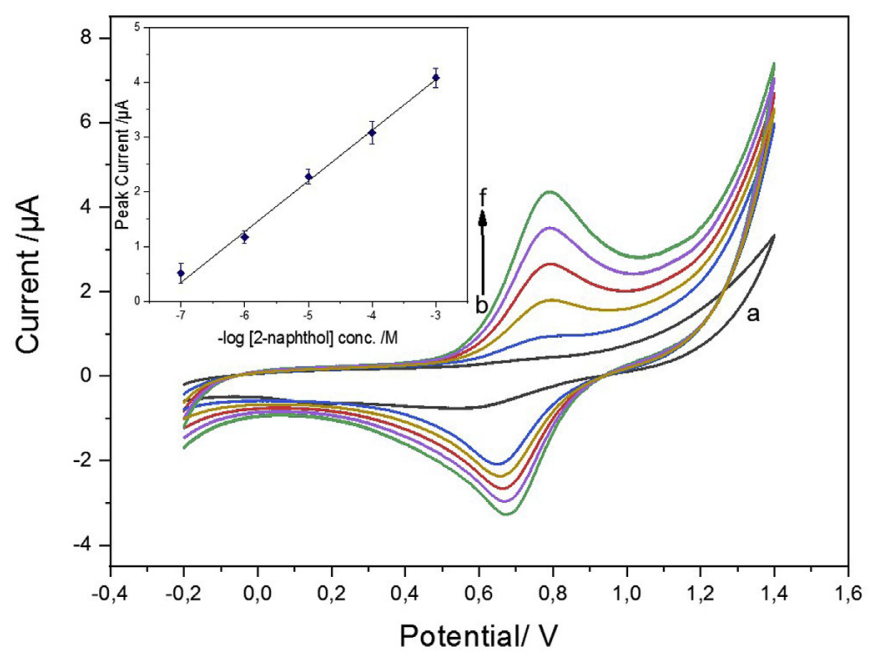

Fig. 4. Response to increasing 2-naphthol concentration (a: $0 \mathrm{M}, \mathrm{b}: 10^{-7} \mathrm{M}, \mathrm{c}: 10^{-6} \mathrm{M}$, $\mathrm{d}: 10^{-5} \mathrm{M}$, e: $\left.10^{-4} \mathrm{M}, \mathrm{f}: 10^{-3} \mathrm{M}\right)$ in TRIS-HCl buffer $(10 \mathrm{mM}, \mathrm{pH} 7.2)$ at the $\mathrm{Cu}(\mathrm{II}) \mathrm{TC} \mathrm{Pc}-$ PAA modified gold electrode; (Insert) Calibration curve as a function of 2-naphthol concentration at the copper phthalocyanine modified gold transducer $[\mathrm{Y}=0.92$ $\mathrm{X}+6.82$ (where $\mathrm{X}$ is the logarithm of 2-naphthol ion concentration (M); and $\mathrm{Y}$ is the peak current $(\mu \mathrm{A}))$ ]. (For interpretation of the references to colour in this figure legend, the reader is referred to the Web version of this article.) 
(A)

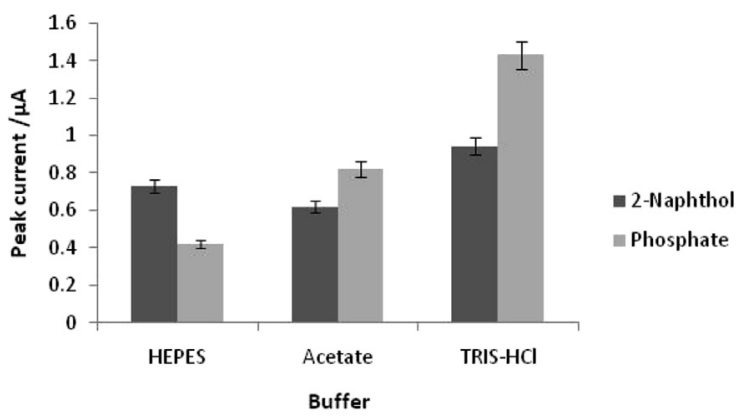

(B)

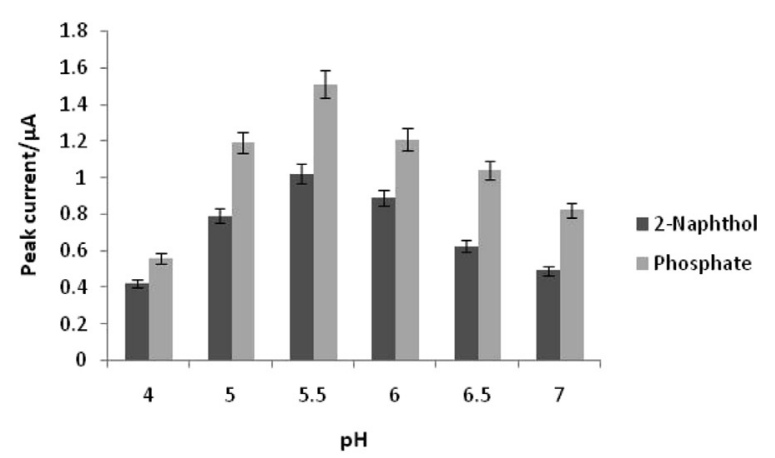

(C)

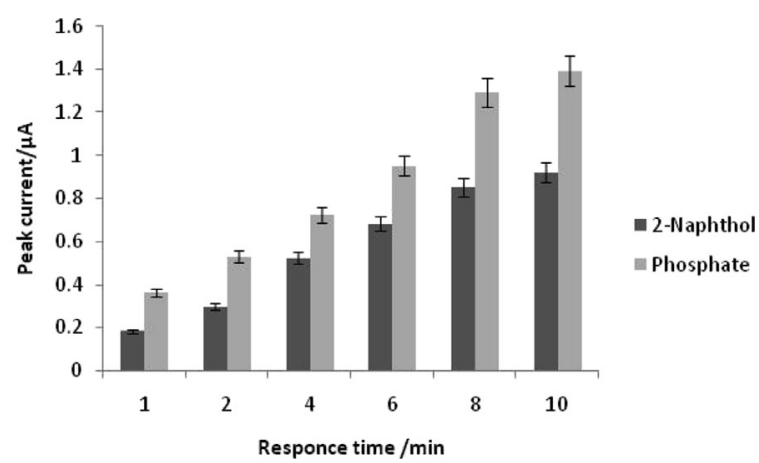

Fig. 5. Influence of (a) buffer type, (b) pH of the buffer solution and (c) incubation time for the $\mathrm{Cu}(\mathrm{II}) \mathrm{TC}$ Pc-PAA modified gold electrode in the presence of $15 \mathrm{nM}$ acid phosphatase. The error bars represent the standard deviation of a duplicate experiment, which was carried out at room temperature.

Naphthol were optimum in the presence of TRIS-HCl buffer which was subsequently selected as the preferred medium. The effect of $\mathrm{pH}$ on the sensor's response to 2-Naphthol and phosphate was examined over the range 3-9 (Fig. 5B). Data revealed that the sensor exhibited a good response in the $\mathrm{pH}$ range 5-6 (dominant species $\mathrm{H}_{2} \mathrm{PO}_{4}^{-}$) and the response decreased $\mathrm{pH}>6$ or $<5$, with maximum obtained at $c a$. pH 5.5 (selected for all further studies). Fig. $5 \mathrm{C}$ shows the effect of incubation time on the acid phosphatase assay performance (15 nM ACP in the presence of $3 \mathrm{mM} 2$-naphthol phosphate) resulting in a signal increase up to 10 min after which there was no further significant increase. A 10 min incubation time and $\mathrm{pH} 5.5$ were thus selected for subsequent assays.

Under the above experimental conditions, the optimum substrate (2-naphthylphosphate) concentration which enabled nonlimited ACP measurement was investigated in the presence of $20 \mathrm{nM}$ ACP. The modified electrode presented a linear response range between 0.001 and $3 \mathrm{mM}$ (Fig. 6), adjusted by the equation

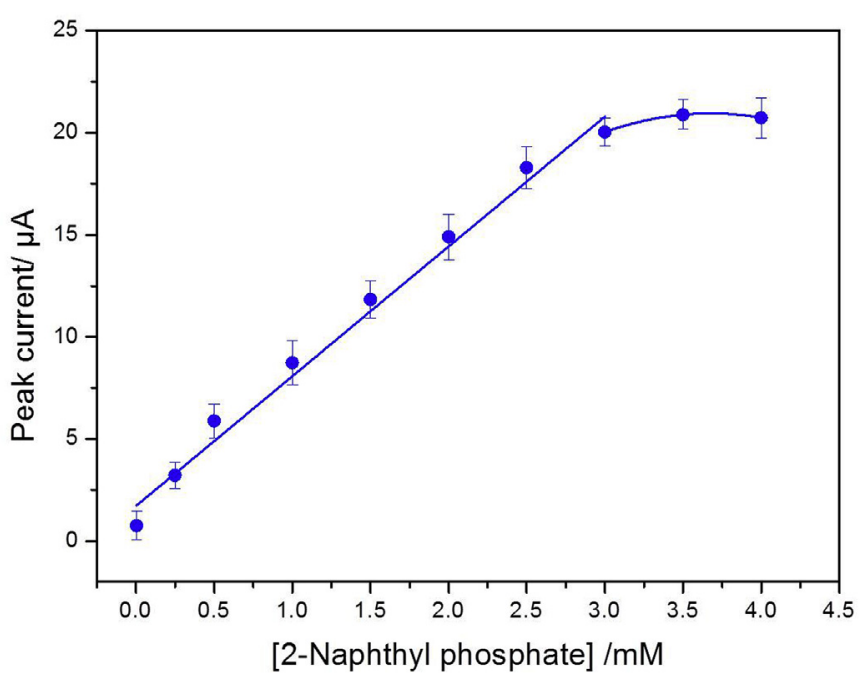

Fig. 6. Anodic current signal for phosphate detection at $\mathrm{E}_{\mathrm{p}}=1.14 \mathrm{~V} v \mathrm{~s} . \mathrm{Ag} / \mathrm{AgCl}$ in response to acid phosphatase conversion $(20 \mathrm{nM})$ as a function of substrate 2-naphthyl phosphate concentration at $\mathrm{Cu}(\mathrm{II}) \mathrm{TC}$ Pc-PAA modified gold screen printed electrode $(n=3)$. (For interpretation of the references to colour in this figure legend, the reader is referred to the Web version of this article.)

$I_{p}=6.5( \pm 0.43)+1.71$ where $I_{p}$ is the peak current $(\mu A)$ and $[N P]$ is the concentration of 2-naphthylphosphate $(\mathrm{mM})$, with a correlation coefficient of 0.9883 for $n=3$. Therefore, $3 \mathrm{mM}$ NP was selected such that the enzymatic reaction rate was not limited by substrate concentration.

Enzyme substrate naphthylphosphate $(3 \mathrm{mM})$ was incubated with ACP $(0.5-20 \mathrm{nM})$ for $10 \mathrm{~min}$ at $37^{\circ} \mathrm{C}$. As shown in Fig. 7A, two peaks were observed, one representing generation of the 2naphthol product with anodic detection at $0.65 \mathrm{~V}$ and the second at $1.14 \mathrm{~V} v s . \mathrm{Ag} / \mathrm{Ag}^{+}$corresponding to the phosphate electrocatalytic signal at the $\mathrm{Cu}$ (II)TC Pc-PAA modified Au surface. Calibration plots are shown in Fig. 7B for enzymatic products (a) naphthol and (b) phosphate detection.

Detection of ACP in spiked bovine serum was then investigated using standard addition in BSA $(0.03 \%)$ with added acid phosphatase enzyme concentrations of $1 \mathrm{nM}, 5 \mathrm{nM}$ and $10 \mathrm{nM}$ (corresponding to $0.23,1.2,2.85 \mathrm{mU} \mathrm{mL}^{-1}$ ) in the presence of $3 \mathrm{mM} \mathrm{2-}$ Naphthyl phosphate. As may be observed from Fig. 8 (slope $1.19 \mathrm{nM} / \mu \mathrm{A} ; \mathrm{R}^{2}=0.9971$ ), there was a good match between the measured experimental values and the nominal concentration of the enzyme in the spiked BSA samples, demonstrating the ability of the catalytic surface to perform quantitatively in this protein matrix. The sensor performance and LOD compares very well to recent acid phosphatase electrochemical detection approaches [9,31] (see Table 2 for comparison) which report detection limits of 0.4 and 1.7 $\mathrm{UL}^{-1}$ respectively.

\section{Conclusion}

In this study, synthesis and characterisation of a copper phthalocyanine derivative ( $\mathrm{Cu}(\mathrm{II}) \mathrm{TC}$ Pc-PAA) enabled indirect detection of the acid phosphatase (ACP) protein biomarker, with the aid of a straightforward drop cast immobilisation approach on Au transducers. The morphological properties of the catalytic material were investigated electrochemically and by means of Raman spectroscopy and scanning electron microscopy (SEM), in order to confirm chemical composition and surface morphology of the film deposited on gold thick film transducers. The electrochemical 

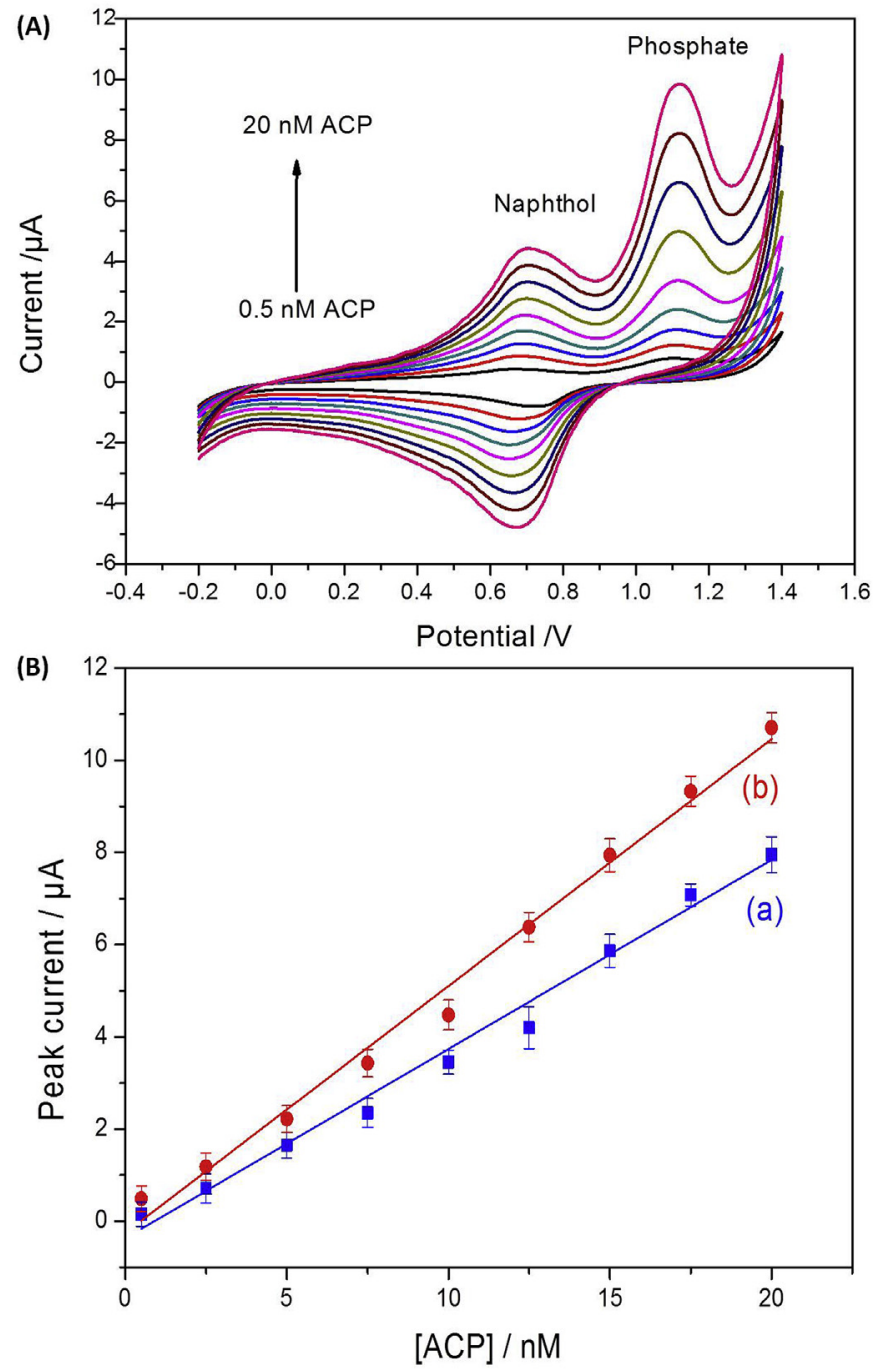

Fig. 7. (A) CV response to increasing ACP concentration at a Cu(II)TC Pc-PAA modified screen printed gold electrode in the presence of $3 \mathrm{mM}$ 2-napthylphosphate in TRIS $\mathrm{HCl}$ buffer (10 mM, pH 5.5). (B) Calibration curves for the generated 2-naphthol (a) and phosphate (b) as a function of acid phosphatase concentrations. (For interpretation of the references to colour in this figure legend, the reader is referred to the Web version of this article.)

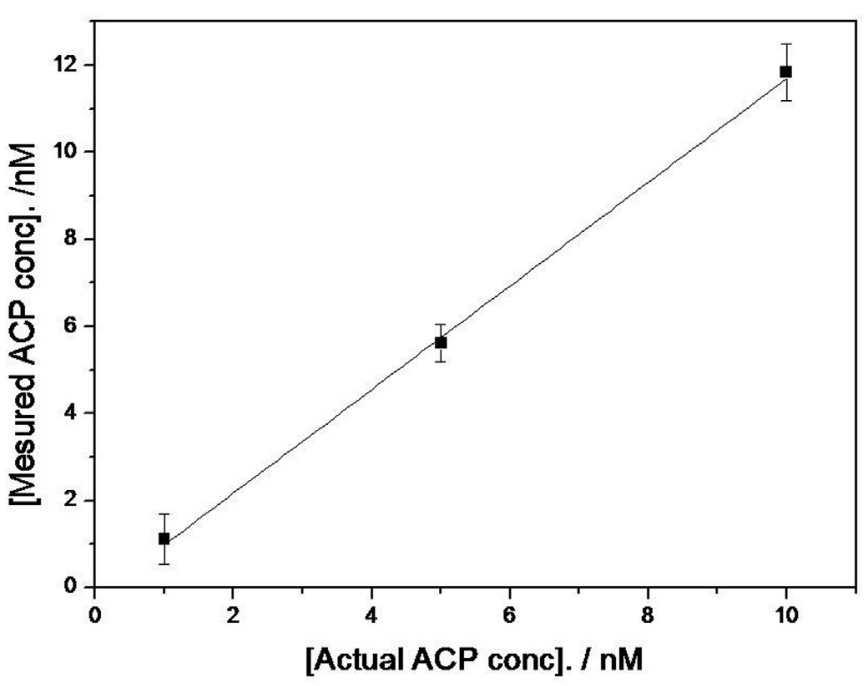

Fig. 8. Correlation plot between actual and measured ACP concentration in bovine serum albumin samples $(0.03 \%)$ utilising the signal arising from phosphate production at the $\mathrm{Cu}(\mathrm{II})$ TC Pc-PAA modified screen printed gold electrode $(\mathrm{n}=3)$.

sensors were tested for the detection of phosphate, and under optimal conditions realised linear range $0.1 \mathrm{nM}-10 \mathrm{mM}$, a detection limit of $0.097 \mathrm{nM}$ with good selectivity with respect to interferent anions at 1000 fold excess levels. Following this, the copper phthalocyanine modified electrode was employed to quantify the biomarker acid phosphatase - exploiting the sensor's dual detection capability of the enzyme reaction products (phosphate and 2naphthol). Operational parameters of the acid phosphatase sensor such as buffer, $\mathrm{pH}$ and incubation time were optimised and a linear response range $0.5-20 \mathrm{nM}$ and LOD of $0.5 \mathrm{nM}$ (corresponding to $0.11 \mathrm{mU} \mathrm{mL}^{-1}$ ) realised for ACP, which is within the relevant clinical range for this biomarker [32]. Spiked BSA studies resulted in excellent recovery of $\mathrm{ACP}$ and further work will extend the approach to quantitation in simulated clinical matrices with the aid of constant potential electroanalytical methodologies.

Table 2

Comparison of reported methods for Acid Phosphatase detection.

\begin{tabular}{|c|c|c|c|}
\hline References & Transducer/catalyst & Technique used & Analytical performance \\
\hline $\begin{array}{l}\text { J. Castañón-Fernández et al. } \\
\text { [31] }\end{array}$ & Flow injection analysis (FIA) & Amperometric & $\begin{array}{l}\text { Linear range: } 0.4-27 \mathrm{U} / \mathrm{L} \\
\text { Detection limit: } 0.4 \mathrm{U} / \mathrm{L}\end{array}$ \\
\hline P. Calvo-Marzal et al. [9] & Nafion modified glassy carbon electrode & $\begin{array}{l}\text { Differential pulse voltammograms } \\
\text { (DPV) }\end{array}$ & $\begin{array}{l}\text { Linear Range: } 9.6-19200 \mathrm{U} / \mathrm{L} \\
\text { Detection limit: } 1.7 \mathrm{U} / \mathrm{L}\end{array}$ \\
\hline Wu et al. [8] & Thick-film magnetoelastic transducer & Resonance frequency/time & $\begin{array}{l}\text { Linear Range: } 1.5-15 \mathrm{mU} \mathrm{mL}^{-1} \\
\text { Detection limit: } \mathrm{U} / \mathrm{L}\end{array}$ \\
\hline Qian et al. [33] & Carbon quantum dots (CQDs) & Fluorescence & $\begin{array}{l}\text { Linear Range: } 18.2-1300 \mathrm{mU} \\
\mathrm{mL}^{-1} \\
\text { Detection limit: } 5.5 \mathrm{mU} \mathrm{mL} \mathrm{mL}^{-1}\end{array}$ \\
\hline Wang el al [7]. & Cysteamine-capped CdTe quantum dots (QDs) & Fluorescence & $\begin{array}{l}\text { Linear Range:1.0-50 mU mL } \\
\text { Detection limit: } 0.45 \mathrm{mU} \mathrm{mL}^{1}\end{array}$ \\
\hline This work & $\begin{array}{l}\text { Copper phthalocyanine } \mathrm{Cu}(\mathrm{II}) \mathrm{Tc} \text { PC-PAA modified screen printed } \\
\text { electrode. }\end{array}$ & Cyclic voltammetry (CV) & $\begin{array}{l}\text { Linear Range:0.11-5.7 mU } \\
\mathrm{mL}^{-1} \\
\text { Detection limit: } 0.11 \mathrm{mU} \mathrm{mL} \mathrm{mL}^{-1}\end{array}$ \\
\hline
\end{tabular}




\section{Acknowledgement}

This work was partially funded by the "SMARTCANCERSENS" project from the European Communities Seventh Framework Program under the Marie Curie IRSES staff exchange programme Grant Agreement PIRSES-GA 2012-318053.

\section{References}

[1] W. Föllmann, S. Weber, S. Birkner, Primary cell cultures of bovine colon epithelium: isolation and cell culture of colonocytes, Toxicol. Vitro Int. J. Publ. Assoc. BIBRA. 14 (2000) 435-445.

[2] W. Na, T. Hu, X. Su, Sensitive detection of acid phosphatase based on graphene quantum dots nanoassembly, Analyst 141 (2016) 4926-4932, https://doi.org/ 10.1039/c6an01087c.

[3] A.K. Dwivedi, P.K. Iyer, Sensitive detection of acid phosphatase enzyme and screening of inhibitors using an anionic polyfluorene derivative, Anal Methods. 5 (2013) 2374-2378, https://doi.org/10.1039/C3AY40233A.

[4] Z. Lin, Z. Liu, H. Zhang, X. Su, Near-infrared fluorescence probe for the determination of acid phosphatase and imaging of prostate cancer cells, Analyst 140 (2015) 1629-1636, https://doi.org/10.1039/C4AN01868K.

[5] G.L. Andriole, E.D. Crawford, R.L. Grubb, S.S. Buys, D. Chia, T.R. Church M.N. Fouad, E.P. Gelmann, P.A. Kvale, D.J. Reding, J.L. Weissfeld, L.A. Yokochi, B. O'Brien, J.D. Clapp, J.M. Rathmell, T.L. Riley, R.B. Hayes, B.S. Kramer G. Izmirlian, A.B. Miller, P.F. Pinsky, P.C. Prorok, J.K. Gohagan, C.D. Berg, Mortality results from a randomized prostate-cancer screening trial, N. Engl. J. Med. 360 (2009) 1310-1319, https://doi.org/10.1056/NEJMoa0810696.

[6] Y. Xu, B. Li, L. Xiao, J. Ouyang, S. Sun, Y. Pang, A colorimetric and near-infrared fluorescent probe with high sensitivity and selectivity for acid phosphatase and inhibitor screening, Chem. Commun. Camb. Engl. 50 (2014) 8677-8680, https://doi.org/10.1039/c3cc49254k.

[7] J. Wang, Y. Yan, X. Yan, T. Hu, X. Tang, X. Su, Label-free fluorescent assay for high sensitivity and selectivity detection of acid phosphatase and inhibitor screening, Sensor. Actuator. B Chem. 234 (2016) 470-477, https://doi.org/ 10.1016/j.snb.2016.05.024.

[8] S. Wu, X Gao, Q Cai, C.A Grimes, A wireless magnetoelastic biosensor for convenient and sensitive detection of acid phosphatase, Sensor. Actuator. B Chem. 123 (2007) 856-859, https://doi.org/10.1016/j.snb.2006.10.033.

[9] P. Calvo-Marzal, S.S. Rosatto, P.A. Granjeiro, H. Aoyama, L.T. Kubota, Electroanalytical determination of acid phosphatase activity by monitoring p-nitrophenol, Anal. Chim. Acta 441 (2001) 207-214, https://doi.org/10.1016/S00032670(01)01120-5.

[10] J. Masin-Spasovska, K. Dimitrovski, S. Stavridis, O. Stankov, S. Dohcev, S. Saidi, K. Jakovski, T. Balkanov, N. Labacevski, V. Stankov, L. Lekovski, G. Spasovski, Acute fulminant hepatatis in kidney transplant recipient after repeated sevoflurane anesthesia-a case report and literature review, Curr. Drug Saf. 8 (2013) 141-144.

[11] M. Evyapan, B. Kadem, T.V. Basova, I.V. Yushina, A.K. Hassan, Study of the sensor response of spun metal phthalocyanine films to volatile organic vapors using surface plasmon resonance, Sensor. Actuator. B Chem. 236 (2016) 605-613, https://doi.org/10.1016/j.snb.2016.05.070.

[12] G. de la Torre, P. Vázquez, F. Agulló-López, T. Torres, Phthalocyanines and related compounds:organic targets for nonlinear optical applications, J. Mater. Chem. 8 (1998) 1671-1683, https://doi.org/10.1039/A803533D.

[13] R. Rella, J. Spadavecchia, G. Ciccarella, P. Siciliano, G. Vasapollo, L. Valli, Optochemical vapour detection using spin coated thin films of metal substituted phthalocyanines, Sensor. Actuator. B Chem. 89 (2003) 86-91, https://doi.org/10.1016/S0925-4005(02)00447-1.

[14] A.D. Gülmez, M.S. Polyakov, V.V. Volchek, S.T. Kostakoğlu, A.A. Esenpinar, T.V. Basova, M. Durmuş, A.G. Gürek, V. Ahsen, H.A. Banimuslem, A.K. Hassan, Tetrasubstituted copper phthalocyanines: correlation between liquid crystalline properties, films alignment and sensing properties, Sensor. Actuator. B Chem. 241 (2017) 364-375, https://doi.org/10.1016/j.snb.2016.10.073.

[15] G. de la Torre, C.G. Claessens, T. Torres, Phthalocyanines: old dyes, new materials. Putting color in nanotechnology, Chem. Commun. 0 (2007) 2000-2015, https://doi.org/10.1039/B614234F.
[16] L. Barhoumi, A. Baraket, N.M. Nooredeen, M.B. Ali, M.N. Abbas, J. Bausells, A. Errachid, Silicon nitride capacitive chemical sensor for phosphate ion detection based on copper phthalocyanine - acrylate-polymer, Electroanalysis 29 (2017) 1586-1595, https://doi.org/10.1002/elan.201700005.

[17] M. Guo, X. Yan, T. Goodson, Electron mobility in a novel hyper-branched phthalocyanine dendrimer, Adv. Mater. 20 (2008) 4167-4171, https:// doi.org/10.1002/adma.200702637.

[18] S. Choi, S.-H. Hong, S.H. Cho, S. Park, S.-M. Park, O. Kim, M. Ree, High-performance programmable memory devices based on hyperbranched copper phthalocyanine polymer thin films, Adv. Mater. 20 (2008) 1766-1771, https://doi.org/10.1002/adma.200702147.

[19] M.N. Abbas, A.L.A. Radwan, P. Bühlmann, M.A.A.E. Ghaffar, Solid-contact perchlorate sensor with nanomolar detection limit based on cobalt phthalocyanine ionophores covalently attached to polyacrylamide, Am. J. Anal. Chem. 02 (2011) 820, https://doi.org/10.4236/ajac.2011.27094.

[20] C.M. Reddy, G.R. Krishna, S. Ghosh, Mechanical properties of molecular crystals-applications to crystal engineering, CrystEngComm 12 (2010) 2296-2314, https://doi.org/10.1039/C003466E.

[21] J. Puigdollers, C. Voz, M. Fonrodona, S. Cheylan, M. Stella, J. Andreu, M. Vetter, R. Alcubilla, Copper phthalocyanine thin-film transistors with polymeric gate dielectric, J. Non-Cryst. Solids 352 (2006) 1778-1782, https://doi.org/10.1016/ j.jnoncrysol.2005.10.063.

[22] S.G. Harroun, J. Bergman, E. Jablonski, C.L. Brosseau, Surface-enhanced Raman spectroscopy analysis of house paint and wallpaper samples from an 18th century historic property, Analyst 136 (2011) 3453-3460, https://doi.org/ 10.1039/c0an00832j.

[23] T. Łuczak, Gold and nanogold electrodes modified with gold nanoparticles and meso-2,3-dimercaptosuccinic acid for the simultaneous, sensitive and selective determination of dopamine and its biogenic interferents, Electroanalysis 26 (2014) 2152-2160, https://doi.org/10.1002/elan.201400313.

[24] G. Inzelt, Recent advances in the field of conducting polymers, J. Solid State Electrochem. 21 (2017) 1965-1975, https://doi.org/10.1007/s10008-0173611-6.

[25] F. Haque, M.S. Rahman, E. Ahmed, P.K. Bakshi, A.A. Shaikh, A cyclic voltammetric study of the redox reaction of $\mathrm{Cu}(\mathrm{II})$ in presence of ascorbic acid in different pH media, Dhaka Univ. J. Sci. 61 (2013) 161-166, https://doi.org/ 10.3329/dujs.v61i2.17064.

[26] L. Fotouhi, A.B. Hashkavayi, M.M. Heravi, Electrochemical behaviour and voltammetric determination of sulphadiazine using a multi-walled carbon nanotube composite film-glassy carbon electrode, J. Exp. Nanosci. 8 (2013) 947-956, https://doi.org/10.1080/17458080.2011.624554.

[27] M. Sharp, M. Petersson, K. Edström, Preliminary determinations of electron transfer kinetics involving ferrocene covalently attached to a platinum surface, J. Electroanal. Chem. Interfacial Electrochem. 95 (1979) 123-130, https:// doi.org/10.1016/S0022-0728(79)80227-2.

[28] A.R.M. Sikkander, C. Vedhi, P. Manisankar, Electrochemical determination of calcium channel blocker drugs using multiwall carbon nanotube-modified glassy carbon electrode, Int. J. Ind. Chem. 3 (2012) 29, https://doi.org/ 10.1186/2228-5547-3-29.

[29] M.N. Abbas, A.L.A. Radwan, N.M. Nooredeen, M.A.A. El-Ghaffar, Selective phosphate sensing using copper monoamino-phthalocyanine functionalized acrylate polymer-based solid-state electrode for FIA of environmental waters, J. Solid State Electrochem. 20 (2016) 1599-1612, https://doi.org/10.1007/ s10008-016-3165-z.

[30] M.-C. Tsai, P.-Y. Chen, Electrochemical detection of 2-naphthol at a glassy carbon electrode modified with tosflex film, Electroanalysis 19 (2007) 1315-1321, https://doi.org/10.1002/elan.200703857.

[31] J. Castañón-Fernández, M.T. Fernández-Abedul, A. Costa-Garcıa, Kinetic determination of acid phosphatase activity by double injection flow analysis with electrochemical detection, Anal. Chim. Acta 413 (2000) 103-108, https:// doi.org/10.1016/S0003-2670(00)00773-X.

[32] I.H. Garba, D. Gatsing, G. Ubom, Elevated total and isoenzyme forms of acid phosphatase in falciparum malaria, C. R. Biol. 329 (2006) 75-78, https:// doi.org/10.1016/j.crvi.2005.12.001.

[33] Z. Qian, L. Chai, Q. Zhou, Y. Huang, C. Tang, J. Chen, H. Feng, Reversible fluorescent nanoswitch based on carbon quantum dots nanoassembly for realtime acid phosphatase activity monitoring, Anal. Chem. 87 (2015) 7332-7339, https://doi.org/10.1021/acs.analchem.5b01488. 